\title{
Population Dynamics of Musca domestica (Diptera: Muscidae): Experimental and Theoretical Studies at Different Temperatures
}

\author{
Carina Aparecida Tardelli ${ }^{1}$, Wesley Augusto Conde Godoy ${ }^{1 *}$ and Paulo Fernando Arruda \\ Mancera $^{2}$ \\ ${ }^{1}$ Departamento de Parasitologia; IB; UNESP; 18618-000; wgodoy@ibb.unesp.br; Botucatu - São Paulo - Brazil. \\ ${ }^{2}$ Departamento de Bioestatística; IB; UNESP; C. P. 510; 18618-000; Botucatu - São Paulo - Brazil
}

\begin{abstract}
In the present study, the population dynamics of $\mathrm{M}$. domestica was evaluated at two different temperatures, 20 and $30^{\circ} \mathrm{C}$. The dynamics was modeled using a density-dependent model of population growth. The temperatures investigated in this study produced no qualitative change in terms of dynamic behaviour, i. e. the population dynamics of M. domestica was characterized by a stable equilibrium at both temperatures. However, the steady state was influenced by the results obtained at different temperatures. The difference between the eigenvalues obtained at the two temperatures was probably the cause of the difference between the distinct steady states. The implications of these results for the population dynamics of $\mathrm{M}$. domestica are discussed.
\end{abstract}

Key words: Population dynamics, Musca domestica, density-dependent model, temperature

\section{INTRODUCTION}

Musca domestica is a species of worldwide distribution (Smith, 1986; Ferreira and Lacerda, 1993) and of medical and veterinary importance since it is a mechanical vector of several diseases (Harwood and James, 1979; Smith, 1986, Levine and Levine, 1991). The pathogens are transported on the fly's cuticle and proboscis, by regurgitation or through the feces (Greenberg, 1970, 1973). Cholera, typhoid fever, amebiasis and poliomyelitis are among the main diseases transmitted by $M$. domestica (Greenberg, 1970, 1973). The successful persistence of $M$. domestica in different regions of the world can be explained by at least two important factors, i.e., a short life cycle and a high growth rate (Ostrolenk and Welch 1942; Rutz and Axtell 1980; Krafsur et al. 1985, Axtell and Arends, 1990). The growth rate is generally influenced by environmental factors (Chapman and Goulson, 2000).

Temperature is an important environmental factor for $M$. domestica population growth, particularly in equatorial and tropical zones, where there is a high density of the species (Levine and Levine, 1991). Temperature has been considered to influence the life history of insects, including $M$. domestica (Chapman and Goulson, 2000). Although some studies have been designed to investigate population behaviour in response to temperature, they have

* Author for correspondence 
focused specifically on geographic variation, genetic divergence and natural selection (Anderson 1972; Huey et al., 1991; Partridge et al., 1994; Santos et al., 1997). In the present study we analyse the theoretical dynamics of $M$. domestica populations kept at two different temperatures, using a density-dependent mathematical model developed by Prout and McChesney (1985), with all parameters estimated in the laboratory.

\section{MATERIAL AND METHODS}

Specimens of $M$. domestica were collected in the vicinity of the UNESP campus, Botucatu, São Paulo State, Brazil. The adult flies were maintained in cages $(30 \mathrm{~cm} \times 30 \mathrm{~cm} \times 30 \mathrm{~cm})$ covered with nylon at 20 and $30 \pm 1^{0} \mathrm{C}$ receiving water and sugar ad libitum. The experiment was performed using laboratory populations which were the progeny of one generation that had completed its life cycle in the laboratory. Exploitative intraspecific competition among immatures, which is known to occur under natural conditions (De Jong, 1976; Lomnicki, 1988), was established in the laboratory at the above temperatures by setting up six larval densities, 100, 200, 400, 600, 800 and 1000 , with two replicates each, developing on $50 \mathrm{~g}$ of rodent diet. Survival was estimated as the number of adults emerging from each vial. Fecundity was measured by counting the number of eggs per female expressed as the average daily egg output based on the length of the gonotrophic cycle of Musca domestica, which is estimated at 10 days (Harwood and James, 1979). The sample size was 20 females per vial. The following difference equation developed by Prout and McChesney (1985) considers the number of immatures, eggs or larvae, in succeeding generations, $n_{t}$ and $n_{t+l}$, and incorporates the variation of the immature density. The model is written as

$$
n_{t+1}=\frac{1}{2} F^{*} S^{*} e^{-(f+s) n_{t}} n_{t}
$$

where $F^{*}$ and $S^{*}$ are the intercepts in the regression analysis of the fecundity and survival as a function of the larval density, respectively. These parameters respectively express the maximum value of fecundity and survival. In this model, half of the population consists of adult females contributing eggs to the next generation. The other two parameters, $f$ and $s$, are regression coefficients that respectively estimate the slope of fecundity and survival on the density of immatures.

Rodriguez (1989) demonstrated that most biological phenomena could be viewed as a Poisson process, which involved a decrease described by an exponential function.

On this basis, there was a strong reason to use exponential regression, in addition to the fact that linear regression produces larger slopes in absolute magnitude resulting in large eingenvalues which did not accurately describe the dynamics at the carrying capacity (Mueller, 1986).

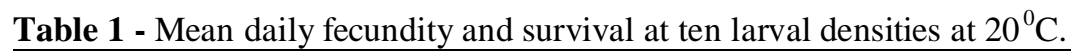

\begin{tabular}{ccc}
\hline Density & $\begin{array}{c}\text { Fecundity }(*) \\
\text { Number of eggs }\end{array}$ & $\begin{array}{c}\text { Survival }(\%) * * \\
\%\end{array}$ \\
\hline 100 & $11.2 \pm 1.36$ & $66 \pm 0.14$ \\
200 & $10.45 \pm 0.99$ & $58 \pm 0.28$ \\
300 & $9.25 \pm 0.96$ & $58 \pm 0.14$ \\
400 & $9.7 \pm 1.21$ & $46.5 \pm 0.07$ \\
500 & $9 \pm 1.25$ & $35 \pm 0.14$ \\
600 & $8 \pm 1.29$ & $44 \pm 0.28$ \\
700 & $7.45 \pm 0.95$ & $45.5 \pm 0.07$ \\
800 & $8.5 \pm 1.35$ & $25.5 \pm 0.4$ \\
900 & $6.85 \pm 0.74$ & $35.5 \pm 0.2$ \\
1000 & $6.55 \pm 0.51$ & $35 \pm 0.07$ \\
\hline
\end{tabular}

$* \mathrm{~N}=20 ; * * \mathrm{~N}=2$ 
Table 2 - Parameters of regression analysis of fecundity and survival on larval densities at $20^{\circ} \mathrm{C}$.

\begin{tabular}{lr}
\hline & Results \\
\hline Maximum $F^{*}$ value for fecundity & 11.7 \\
& 0.14 \\
Regression coefficient $(f)$ & $5.6 \times 10^{-4}$ \\
& $\pm 3.22 \times 10^{-5}$ \\
T value & 122 \\
$\mathrm{r}^{2}$ & 60.0 \\
Anova & 304 \\
Maximum $S^{*}$ value for survival & 0.67 \\
& 0.06 \\
Regression coefficient $(s)$ & $7.9 \times 10^{-4}$ \\
& $\pm 1.38 \times 10^{-4}$ \\
T value & 4.71 \\
$\mathrm{r}^{2}$ & 64 \\
Anova & 32.5 \\
\hline
\end{tabular}

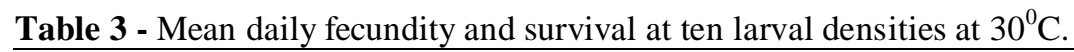

\begin{tabular}{lcc}
\hline Density & Fecundity* & Survival $(\%)^{* *}$ \\
\hline 100 & $11.4 \pm 0.88$ & $81.5 \pm 0.2$ \\
200 & $10.3 \pm 1.55$ & $71.5 \pm 0.2$ \\
300 & $8.55 \pm 0.82$ & $51.5 \pm 0.2$ \\
400 & $8 \pm 0.72$ & $43 \pm 0.4$ \\
500 & $6.25 \pm 1.01$ & $42 \pm 0.4$ \\
600 & $5.45 \pm 0.88$ & $42 \pm 0.2$ \\
700 & $4.5 \pm 1.1$ & $41.5 \pm 0.3$ \\
800 & $4.05 \pm 0.88$ & $43.5 \pm 0.4$ \\
900 & $3.4 \pm 0.99$ & $42 \pm 0.14$ \\
1000 & $3.35 \pm 0.98$ & $40.5 \pm 0.4$ \\
\hline
\end{tabular}

$* \mathrm{~N}=20 ; * * \mathrm{~N}=2$

\section{RESULTS}

Tables 1 and 2 present the results obtained at $20^{\circ} \mathrm{C}$, and Tables 3 and 4 the results obtained at $30^{\circ} \mathrm{C}$. Tables 1 and 3 show that the fecundity and the survival of $M$. domestica decrease with increasing immature density. Tables 2 and 4 show exponential regression slopes for both fecundity and survival that are significantly different from zero $(\mathrm{P}<0.001)$. Tables 2 and 4 also present the values of $F^{*}, S^{*}, f$ and $s$, and then the difference equation (1) for the temperatures of $20^{\circ} \mathrm{C}$ and $30^{\circ} \mathrm{C}$ is respectively given by

$$
\begin{aligned}
& n_{t+1}=\frac{1}{2} 11.7 e^{-0.00056 n_{t}} 0.67 e^{-0.00079 n_{t}} n_{t}, \\
& n_{t+1}=\frac{1}{2} 13.4 e^{-0.00152 n_{t}} 0.69 e^{-0.00068 n_{t}} n_{t} .
\end{aligned}
$$

The patterns of competition described by equations (2) and (3) could be analysed by observing the trajectory of the populations in subsequent generations (Figure 1 for $20^{\circ} \mathrm{C}$ and Figure 2 for $30^{\circ} \mathrm{C}$ ). The line of $45^{\circ}$ intercepted the function at the steady state and the theoretical number of immatures in equilibrium was 1003 at 20 and 721 at $30^{\circ} \mathrm{C}$. The population dynamics of $M$. domestica was described by a monotonic equilibrium (Figures 3 and 4) at both temperatures. For these iterations, no qualitative difference was observed in populations from different temperatures, just a quantitative difference characterized by the different population sizes. 
Table 4 - Parameters of regression analysis of fecundity and survival on larval densities at $30^{\circ} \mathrm{C}$.

\begin{tabular}{lr}
\hline & Results \\
\hline Maximum $F^{*}$ value for fecundity & 13.4 \\
& 0.51 \\
Regression coefficient $(f)$ & $1.52 \times 10^{-3}$ \\
& $\pm 4.98 \times 10^{-5}$ \\
T value & 84.35 \\
$\mathrm{r}^{2}$ & 82.0 \\
Anova & 937 \\
Maximum $S^{*}$ value for survival & 0.69 \\
& 0.055 \\
Regression coefficient $(s)$ & $6.8 \times 10^{-4}$ \\
& $\pm 1.37 \times 10^{-4}$ \\
T value & 4.34 \\
$\mathrm{r}^{2}$ & 57 \\
Anova & 24.1 \\
\hline
\end{tabular}

$\mathrm{P}<0.001$

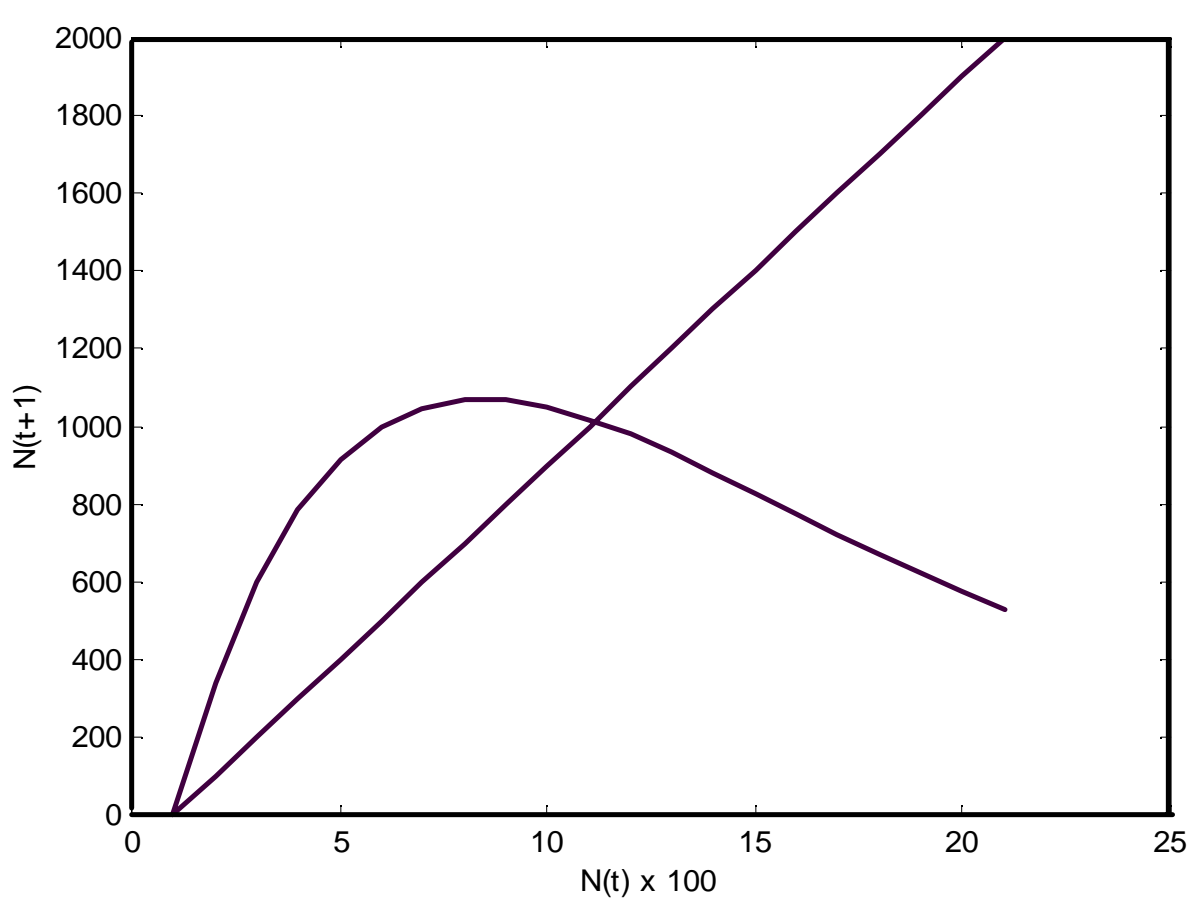

Figure 1 - Recurrence of the number of immatures at $20^{\circ} \mathrm{C}$. 


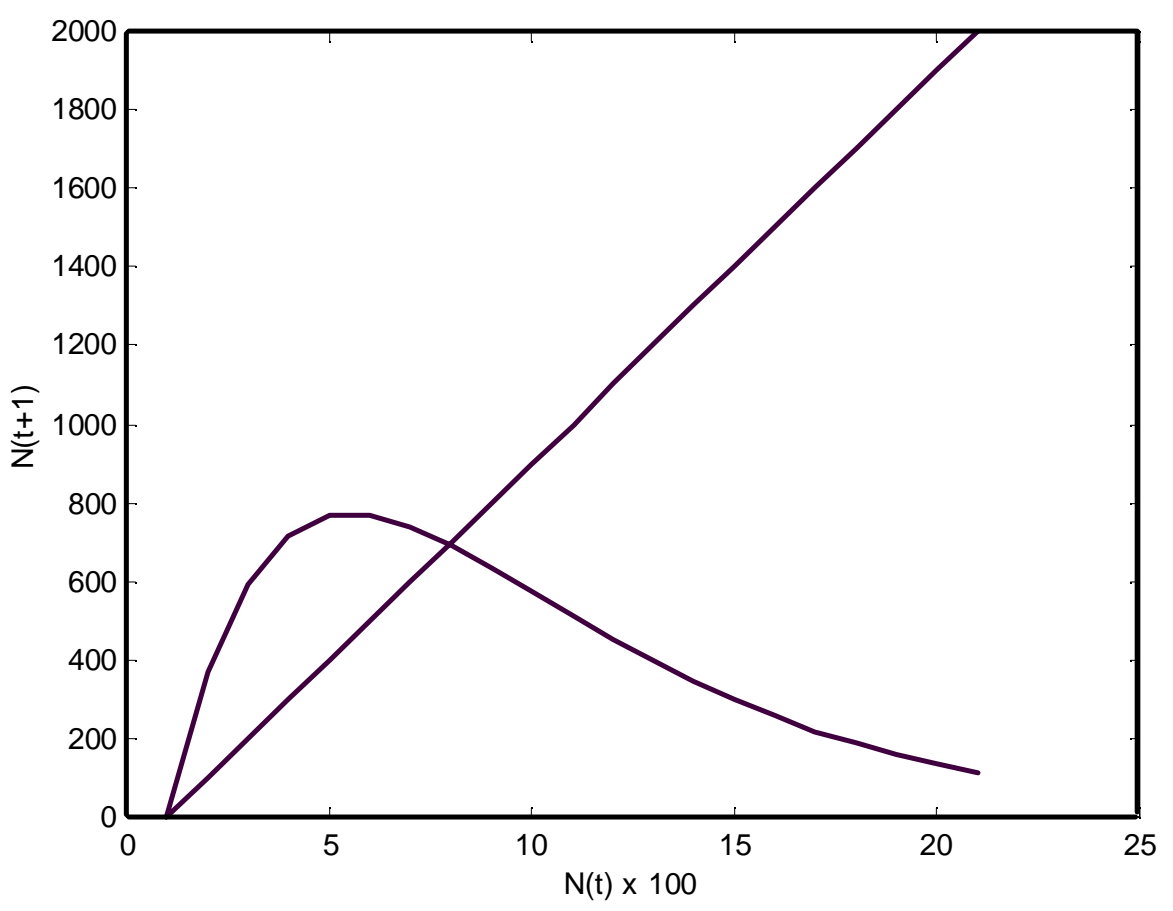

Figure 2 - Recurrence of the number of immatures at $30^{\circ} \mathrm{C}$.

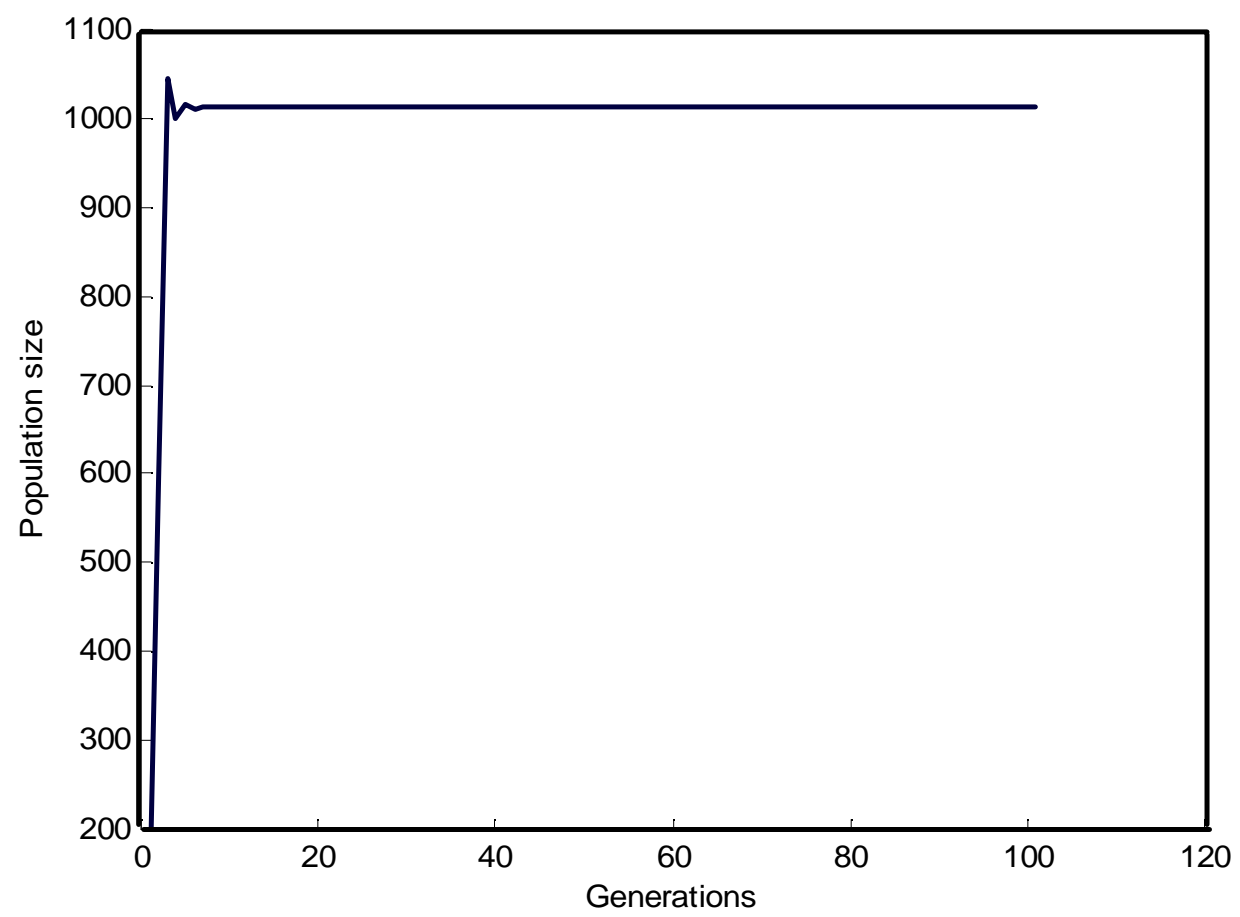

Figure 3 - Evolution of the population across generations at $20^{\circ} \mathrm{C}$. 


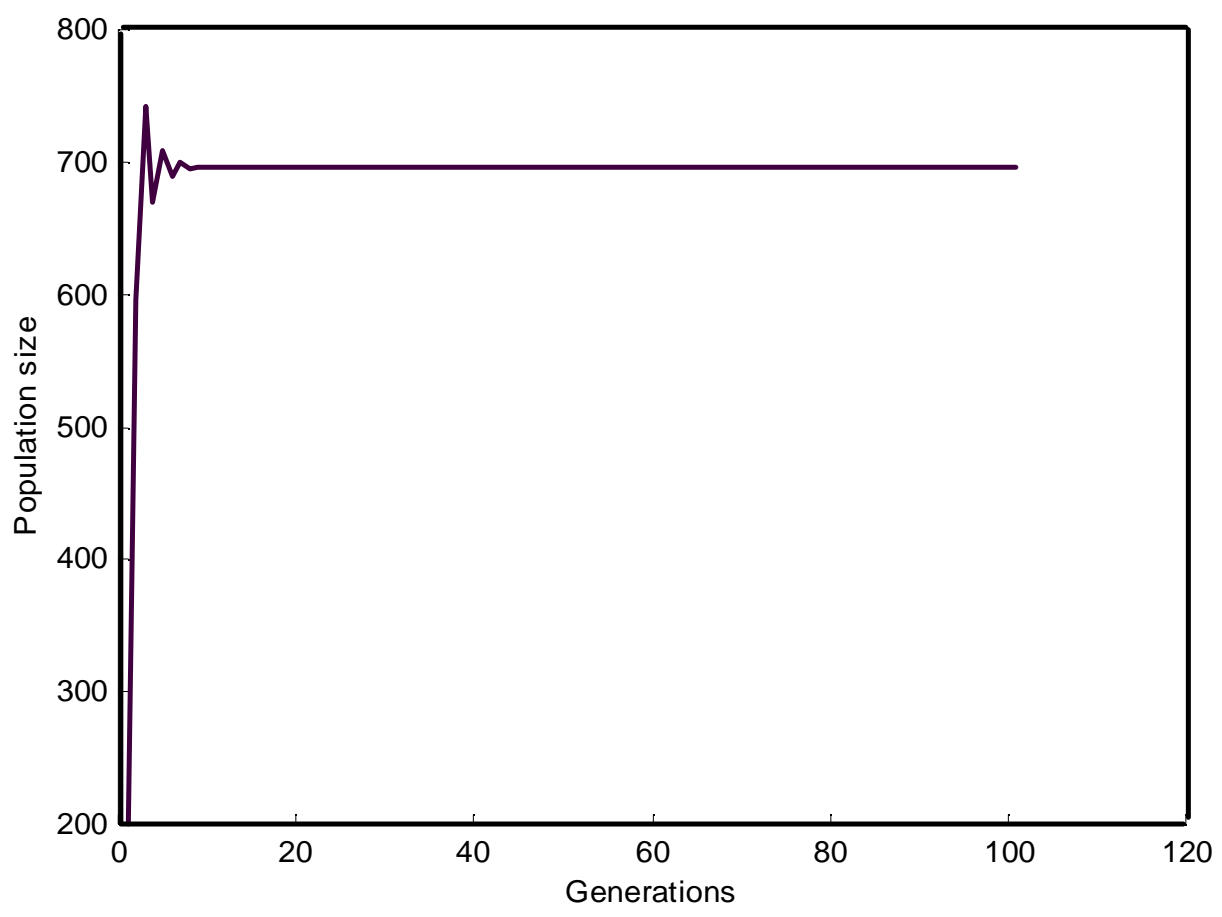

Figure 4 - Evolution of the population across generations at $30^{\circ} \mathrm{C}$.

\section{DISCUSSION}

Fecundity and survival decreased as a function of larval densities at both temperatures investigated. Similar results have been observed in blowfly populations (Von Zuben et al., 1993; Godoy et al., 1993; Reis et al., 1996; Godoy et al., 1997, 2001; Silva et al., 2003). Competition for food has been investigated in insect populations and Nicholson (1954) divided competition into the scramble and contest modes. The concept of the two forms of competition is probably much more associated with their ecological outcomes than the underlying behaviour involved. Gains of competitors in contests are all or nothing, whereas in scrambles, all individuals achieve some gains, if sometimes less than enough to survive and/or reproduce (Parker, 2000). The pattern of competition exhibited by both blowflies and $M$. domestica was scramble since there was a homogenous distribution of resources among the individuals that competed for food (Von Zuben et al., 1993; Godoy et al., 1993; Silva et al., 2003). In this sense, standard deviations seemed to exhibit an apparently small magnitude in response to the kind of food distribution.

The temperatures investigated in this study produced no qualitative change in terms of dynamic behaviour, i. e. the population dynamics of $M$. domestica was characterized by a stable equilibrium at both temperatures. However, the steady state was influenced by the results obtained at different temperatures. The difference between the eigenvalues obtained at the two temperatures was probably the cause of the difference between the distinct steady states.

Stability of equilibrium has been investigated in insect populations (Dennis et al., 1995; Costantino et al., 1995, 1997, 1998; Cushing et al., 1998) and perhaps the most important question arising in this context is what governs the transitions from stable to unstable equilibrium. The effects produced by the manipulation of parameter values are well known in theoretical population models (May and Oster, 1976; Edelstein-Keshet, 1998) and evidence for such changes comes from theoretical and empirical studies (Cavalieri and Koçak, 1995; Costantino et al., 1995, 1997; Dennis et al., 1995, 1997). Experiments designed to test predictive models have shown that shifts in dynamic behavior 
can occur from monotonic stable equilibrium to stable cycles, to aperiodic cycles in response to changes in adult mortality (Costantino et al., 1995, 1997; Dennis et al., 1995, 1997; Godoy et. al., 2001).

The absence of change of dynamic behavior observed in $M$. domestica suggested that the species tended to keep a monotonic stable dynamics. Prout's model has also been used to understand the dynamics of three invader blowfly species, $C$. megacephala, $C$. putoria and $C$. albiceps, and two native species, $C$. macellaria and Lucilia eximia (Godoy et al., 1993; Von Zuben et al., 1993; Godoy et al., 1996; Reis et al., 1996; Godoy et al., 1997; Teixeira et al., 1998; Silva et al., 1999; Godoy et al., 2001; Silva et al., 2003). Lucilia eximia and C. macellaria are blowfly species which exhibit the same behavior, showing stable equilibrium (Godoy et al., 1997; Silva et al., 2003). On the other hand, all Chrysomya species have shown a two-point limit cycle (Godoy et al., 2001). We strongly believed that these results occured as a function of the demographic parameters, survival and fecundity, which were of small magnitude in $M$. domestica, L. eximia and $C$. macellaria if compared to other fly species, such as C. megacephala, C. putoria and C. albiceps (Reis et al., 1996; Godoy et al., 1997, 2001). Effectively, $M$. domestica has a smaller body size than blowflies and this factor is certainly associated with its fecundity (Reis et al., 1994).

It was interesting to observe that, even though $M$. domestica was a cosmopolitan species highly successful in terms of colonization, its body size was small and its fecundity low if compared to most blowflies. Could be possible that the success of species such as M. domestica and L. eximia may be attributed to the low magnitude of their demographic parameters. This profile may involve fewer requirements in terms of carrying capacity than in species which show limit cycles such as Chrysomya species, or any more complex behavior. Based on these results, we believed that the success of $M$. domestica was probably associated with both its life history and its population dynamics. The stable equilibrium seems to provide suitable conditions for the success of some fly species. Studies of this nature are important, mainly on species of sanitary importance, since they may describe population trends important for invader and cosmopolite species within a context of dispersal, invasion and colonization of new areas.

\section{ACKNOWLEDGEMENTS}

CAT has been supported by research fellowships from FAPESP (00-2874-8). PFMA has received financial support from FAPESP (01/09681-3).

\section{RESUMO}

Neste estudo a dinâmica populacional de $M$. domestica foi avaliada em duas temperaturas, $20^{\circ}$ e $30^{\circ}$ C. A dinâmica foi modelada utilizando um modelo de crescimento populacional dependente da densidade. As temperaturas investigadas no estudo não produziram mudança qualitativa em termos de comportamento dinâmico, ou seja, a dinâmica populacional de $M$. domestica foi caracterizada por um equilíbrio estável em ambas as temperaturas. Entretanto, o ponto de equilíbrio foi influenciado pelos resultados obtidos nas diferentes temperaturas. A diferença entre os autovalores obtidos nas duas temperaturas foi a provável causa da diferença entre os pontos de equilíbrio. As implicações destes resultados para a dinâmica populacional de $M$. domestica são discutidas.

\section{REFERENCES}

Anderson, W. W. (1972), Genetic divergence in body size among experimental populations of Drosophila pseudoobscura kept at different temperatures. Evol., 27, 278-284.

Axtell, R. C. and Arends, J. J. (1990), Ecology and management of arthropod pests of poultry. Ann. Ver. Entomol., 35, 101-126.

Cavalieri, L. F. and Koçak, H. (1995), Intermittent transition between order and chaos in an insect pest population. J. Theor. Biol., 175, 231-234.

Chapman, J. W. and Goulson, D. (2000), Environmental versus genetic influences on fluctuating asymmetry in the house fly, Musca domestica. Biol. J. Linn., 70, 403-413.

Costantino, R. F.; Cushing, J. M.; Dennis, B. and Desharnais, R. A. (1995), Experimentally induced transitions in the dynamic behaviour of insect populations. Nature, 375, 227-230. 
Costantino, R. F.; Desharnais, R. A.; Cushing, J. M. and Dennis, B. (1997), Chaotic dynamics in an insect population. Science, 275, 389-391.

Costantino, R. F.; Cushing, J. M.; Dennis, B.; Desharnais, R. A. and Henson, S. M. (1998), Resonant population cycles in temporally fluctuating habitats. Bull. Mat. Biol., 60, 247-273.

Cushing, J. M.; Dennis, B.; Desharnais, R. A. and Costantino, R. F. (1998), Moving toward an unstable quilibrium: saddle nodes in population systems. J. Anim. Ecol., 67, 298-306.

De Jong, G. (1976), A model of competition for food. I. Frequency-dependent viabilities. Am. Natur., 110, 1013-1027.

Dennis, B. R.; Desharnais, A.; Cushing, J. M. and Costantino, R. F. (1995), Nonlinear demographic dynamics: mathematical models, statistical methods and biological experiments. Ecol. Monog., 65, 261281.

Dennis, B. R.; Desharnais, A.; Cushing, J. M. and Costantino, R. F. (1997), Transitions in population dynamics: equilibria to periodic cycles to aperiodic cycles. J. Anim. Ecol., 66, 704-729.

Edelstein-Keshet, L (1988), Mathematical models in biology. NewYork : Random House.

Ferreira, M. J. M. and Lacerda, P. V. (1993), Muscóides sinantrópicos associados ao lixo urbano em Goiânia, GO. Rev. Bras. Zool., 10, 185-195.

Godoy, W. A. C.; Reis, S. F.; Von Zuben, C. J. and Ribeiro, O. B. (1993), Population dynamics of Chrysomya putoria (Diptera: Calliphoridae). J. Appl. Ent., 116,163-169.

Godoy, W. A. C.; Von Zuben, C. J.; Reis, S. F. and Von Zuben, F. J. (1996), Dynamics of experimental populations of native and introduced blowflies (Diptera: Calliphoridae): mathematical modelling and transition from asymptotic equilibrium to bounded oscillations. Mem. Inst. Oswaldo Cruz, 91, 641-647.

Godoy, W. A. C.; Von Zuben, C. J.; Reis, S. F.; Von Zuben, F. J. (1997), The spatial dynamics of native and introduced blowflies (Dipt. Calliphoridae). $J$. Appl. Ent., 121, 305-309.

Godoy, W. A. C.; Von Zuben, C. J.; Reis, S. F.; Von Zuben, F. J. (2001), Spatio-temporal dynamics and transition from asymptotic to bounded oscillations in Chrysomya albiceps (Diptera, Calliphoridae). Mem. Inst. Oswaldo Cruz, 96, 627-634.

Greenberg, B. (1970), Flies and disease. Ecology, classification and biotic associations. New Jersey : Univ. Press Princeton. v. 1.

Greenberg, B. (1973), Flies and disease. Biology, disease transmission. New Jersey : Univ. Press Princeton. v. 2.
Harwood, R. F. and James, M. T. (1979), Entomology in human and animal health. New York : Macmillan.

Huey, R. B.; Partridge, L. and Fowler, K. (1991), Thermal sensitivity of Drosophila melanogaster responds rapidly to laboratory natural selection. Evol., 45, 751-756.

Krafsur, E. S.; Black IV, W. C.; Church, C. J. and Barnes, D. A. (1985), Age structure and reproductive biology of a natural house fly (Diptera: Muscidae). Popul. Environ. Entomol., 14, 159-164.

Levine, O. S. and Levine, M. M. (1991), Houseflies (Musca domestica) as mechanical vectors of Shigellosis. Infect. Immun., 31, 445-452.

Lomnicki, A. (1988), Population Ecology of Individuals. Princeton : Princeton University Press.

May, R. M. and Oster, G. F. (1976), Bifurcations and dynamics complexity in simple ecological models. Am. Nat., 110, 573-599.

Mueller, L. D. (1986), Density-dependent rates of population growth-estimation in laboratory populations. Am. Nat., 128, 282-293.

Nicholson, A. J. (1954), An outline of the dynamics of animal populations. Aust. J. Zool., 2, 9-65.

Ostrolenk, M. and Welch, H. (1942), The common house fly (Musca domestica) as a source of pollution in food establishments. Food. Res., 7, 192-200.

Ostrolenk, M. and Welch, H.(1942), The house fly as a vector of food poisoning organisms in food producing establishments. Am. J. Publ. Hlth., 32, 487-494.

Parker, G. A. (2000), Scramble in behaviour and ecology. Philos. Trop. Roy. Soc. B, 355, 1637-1645.

Partridge, L.; Barrie, B.; Fowler, K. and French, V. (1994), Evolution and development of body and cell size in Drosophila melanogaster in response to temperature. Evol., 48, 1269-1276.

Prout, T. and McChesney, F. (1985), Competition among immatures affects their adult fertility: population dynamics. Am. Natur., 126, 521-558.

Reis, S. F.; Stangenhaus, G.; Godoy, W. A. C.; Von Zuben, C. J. and Ribeiro, O. B. (1994), Variação em caracteres bionômicos em função da densidade larval em Chrysomya megacephala e Chrysomya putoria (Diptera: Calliphoridae). Rev. Bras. Ent., 38, 33-46.

Reis, S. F.; Teixeira, M. A.; Von Zuben, F. J.; Godoy, W. A. C.; Von Zuben, C. J. (1996), Theoretical dynamics of experimental populations of introduced and native blowflies. J. Med. Ent., 33, 537-544.

Rodriguez, D. J. (1989), A model of population dynamics for the fruit fly Drosophila melanogaster with density dependence in more than one life stage and delayed density effects. J. Anim. Ecol., 58, 349-365. 
Rutz, D. A. and Axtell, R. C. (1980), House fly (Musca domestica) (Diptera: Muscidae) parasites associated with poultry manure in North Carolina. Environ. Entomol., 9, 175-180.

Santos, M.; Borash, D. J.; Joshi, A.; Bounlutay, N. and Mueller, L. D. (1997), Density-dependent natural selection in Drosophila: evolution of growth rate and body size. Evol., 51, 420-432.

Silva, I. C. R.; Mancera, P. F. and Godoy, W. A. C. (1999), Efeito da temperatura na dinâmica populacional de Chrysomya megacephala. In: Encontro Regional de Biomedicina. UNESP, Botucatu, SP.

Silva, I. C. R.; Mancera, P. F. and Godoy, W. A. C. (2003), Population dynamics of Lucilia eximia (Dipt., Calliphoridae). J. Appl. Ent., 127, 2-6.

Smith, K. G. V. (1986), A manual of forensic entomology. Oxford : University Printing House.

Teixeira, M. A.; Von Zuben, F. J.; Godoy, W. A. C.; Von Zuben, C. J. and Reis, S. F. (1998), Delayed density dependence at the immature stage in insects and the dynamic behavior of nonlinear difference equations. Cienc. Cult., 50, 268-272.

Von Zuben, C. J.; Reis, S. F.; Do Val, J. B. R.; Godoy, W. A. C. and Ribeiro, O. B. (1993), Dynamics of a mathematical model of Chrysomya megacephala (Diptera: Calliphoridae). J. Med. Ent.,30, 443-448. 